\title{
The Interaction of Economic Livelihood Strategies and Literacy and Numeracy Practices of Urban Gambian Women with Low Educational Attainments
}

\author{
Haddy Njie \\ North Carolina State University, USA \\ E-mail: hmnjie@ncsu.edu
}

Received: 24-06- 2016

doi:10.7575/aiac.ijels.v.4n.3p.73

Accepted: $20-07-2016$

Published: 31-07-2016

URL: http://dx.doi.org/10.7575/aiac.ijels.v.4n.3p.73

\begin{abstract}
This paper is based on eight months of ethnographic fieldwork in the periphery of Banjul, the capital of The Gambia. It explores relations between the gender roles of women with modest educational achievement and their uses of literacy and numeracy. The paper applied New Literacy Studies theoretical framework of literacy as a 'social practice'. Data was collected from 120 women with low and no educational qualifications in the urban Gambia who participated in the three different stages of the study, namely: survey, focus group discussions and individual interviews along with participant observations. The study data was analyzed through the use of both qualitative and quantitative data analysis techniques. The survey data was analyzed and presented in the form of descriptive statistics for illuminating the demographic characteristics of the study participants. The analysis of the qualitative data was done through the use of both inductive and deductive coding strategies for identifying common themes and patterns across the different data sources. In this paper, a detailed ethnographic account of four cases of women who participated in the study is provided for illuminating the literacy environment as well as the circumstances subsumed within it that induce or suppress literacy practices among women of limited educational qualifications in The Gambia. The study uncovers instances where women's uses of literacy and numeracy added greater efficiency in their economic activities and highlight other scenarios where literate women did not rely on those skills in the exercise of their economic activities. Findings confirm New Literacy Studies (NLS) theoretical claim that literacy skills do not automatically create their uses. Rather, literacy uses are a product of their socio-cultural context of their application. From the four cases reported here, this paper substantially illuminates women's economic livelihood strategies, the contextual barriers they encounter in performing their economic roles and their opportunities and limitations for using and sharpening their written numeracy and literacy skills. Knowledge concerning the interaction of women's economic livelihoods and literacy uses constitutes critical information that could inform adult education and economic policy development in Sub-Saharan Africa.
\end{abstract}

Keywords: Gender and development; Informal economy \& Women's economic livelihoods; Women's literacy; The Gambia

\section{Introduction}

\subsection{Problem}

Traditional patterns of inquiry into women's literacy (Burchfield, Hua, Baral, \& Rocha, 2002; Hill \& King, 1993; Kagitcibasi, Goksen, \& Gulgoz, 2005) have focused their analysis on its putative impact on a variety of development proxies like empowerment, health status and material well-being, while mostly ignoring the critical question of how such results are produced and/or why they are not. This myopia parallels similar failings in general attempts to address the linkage between literacy and development, illustrated in the works of researchers such as Goody $(1986,1987)$ and Ong (1982), who consider literacy per se as the prime factor responsible for developing human rationality and the ability to think in decontextualized ways (Purcell-Gates, 2007), and so ipso facto the key to explaining socio-economic change. As a consequence, these authors typically take little account of the environment in which it is acquired and hopefully applied. Unfortunately, this view has been widely mirrored by international agencies in their promotion of literacy and numeracy among the poor in developing societies - and related policies have, as a result, been criticized for a tendency to assume that the mere ability to read and write will itself confer automatic socio-economic benefits (Maddox, 2007; RobinsonPant, 2004; Rogers, 2001 Street, 1995; 2004).

Arguably, one key remedy to these oversights lies in paying much closer attention to just what women of modest educational attainments or literacy competence actually $d o$ - under a variety of circumstances - with whatever such skills they have managed to acquire. However, there has been very little research on this topic conducted on women of the global south- and of Africa in particular- where international agency literacy programs are predominantly located (for 
examples of the few studies dealing partly or substantially with the topic (see Gebre et al., 2009; Kalman, 2001; Mein, 2010; Prins, 2008; Puchner, 2003).

\subsection{Study Objective}

This article addresses the foundations of broad claims about literacy's potency in developing countries by examining the patterns of literacy and written numeracy usage among urban Gambian women of modest educational attainments and the interaction of such patterns with their economic activities. It draws on eight months of ethnographic research in the periphery of Banjul, the capital of The Gambia, to analyze relations between women's economic livelihoods and their literacy and numeracy practices. Results are based on a mix of data collection approaches, including ethnographic survey, focus group discussions and an in-depth ethnographic case study. An effort is made to depict the contextual and structural barriers that limit women's uses of literacy and numeracy skills as well as the ways in which they nonetheless apply and enhance such knowledge. At the same time, it is demonstrated that an understanding of women's actual uses of literacy and numeracy helps greatly clarify the economic activities that they perform in the communities where they live.

\subsection{Research Questions}

The research questions that were explored to analyze the interaction of economic activities and literacy and written numeracy usages are:

1. What are the principal economic activities that urban Gambian women with low educational attainments carry out on a regular basis and what usages are able to make of their literate and numerate skills in those activities?

2. How do they assess the utility of literacy and written numeracy in their daily lives and the conditions that most favor their usage and improvement of these skills?

The following sections are devoted successively to review of related literature and practice, a depiction of the methodology developed for the study, presentation and analysis of the data assembled and discussion of the study's findings and conclusions.

\section{Literature Review}

\subsection{Gender and Development in Sub-Saharan Africa}

In developing societies like those of Sub-Saharan Africa, women typically reap smaller benefits from their participation in paid work than men for a series of reasons: they have less access to high-paying jobs, possess less valued human capital skills and are little represented in institutions where critical decisions regarding their well-being are made (Glick and Sahn, 1997; Luci, Jütting and Morrisson, 2012). At the same time, home care duties monopolize much of the time that they have available for paid work (Blackden and Wodon, 2006; Kes and Swaminathan, 2006). The equity and welfare issues faced by women in Sub-Saharan Africa and developing societies in general have been attributed to their lack of access to and control over resources, their lower educational attainments relative to men, the continuous scarcity of formal sector jobs - even when they are educated - and the persistence of cultural bias (Chant, 2007; Darkwah, 2010; Tsikata, 2009). The gender and development literature thus establishes a nexus between being a woman and being poor in much of the developing world, one resulting from bias and gender entrenched practices that discriminate against women and bar them from access to resources needed for improving their life chances.

\subsection{The Informal Economy and Women's Economic Activities}

The informal economy broadly describes the commercial spaces that allow for the exchange of goods and services, with much of such economic activities conducted out of the radar of government control for taxes (Günther and Launov, 2012). In developing countries such as The Gambia, the informal economy is a common site for economic transactions as reported in numerous studies (Colette, 2011; Lince, 2011). In describing the informal economy, Colette (2011) notes that in the metropolitan areas of Africa, Latin America, and Asia, Sidewalks, marketplaces, and small harbors are visible and vital spaces for the exchange of goods and services. The informal economy plays significant roles in employment creation, production and income generation in many countries of the developing world and has, in countries with high rates of rural-urban drift, such as The Gambia, absorbed most of the expanding labor force in the urban areas (International Labor Organization, 2014). Participation in the informal economy is characterized by self-employment and comprising a great share of informal employment than wage employment. The informal sector has been growing in Sub-Saharan Africa, and it accounts for a huge share of non-agricultural employment, ranging from 33 percent in South Africa to 82 percent in Mali (International Labor Organization, 2014). The informal economy is specifically suited to the nature of the economic activities of a vast majority of Sub-Saharan African women as mainly vendors of comestibles and other basic household needs. Consequently, a vast majority of women participate in the informal economy. As an example, 84 percent of women non-agricultural workers in Sub-Saharan Africa earn incomes through their participation in the informal economy compared to 63 percent of men (Chen, 2005). This pattern of women's participation in the informal economy in SubSaharan Africa typifies the case of urban Gambian women with low socio-economic status and educational attainments.

\subsection{Women's Literacy}

A number of strategies have been developed and applied throughout the developing world to use educational programs to improve the living conditions of women and end the vicious circle of poverty that not only affects them and their families. One of these strategies has been the introduction of integrated adult literacy programs -- similar in some respects to the ones that became popular as a strategy in the 1960s and 1970s for enhancing efficiency and productivity in economic 
activities throughout the developing world (Yousif, 2003, cited by Fransman, 2005) but specifically targeting women and girls in resource-poor and marginalized communities. As Street (2004) notes, when large-scale functional literacy programs were first launched in developing countries in the 1960s with international support, it was anticipated that adult literacy would radically improve the lives of the illiterate poor - though the evidence on the ground (e.g., Easton, 1983) was not very supportive. That rather naïve faith was rooted in the assumption that the mere acquisition of literacy skills will increase productivity, improve social standing and transform the lives of beneficiaries irrespective of the context in which they lived or the particular nature of their needs. However, research has shown that large-scale programs to improve the lives of people in developing countries through literacy tend to fall short of expected outcomes (Prins, 2008). Available studies attribute these disappointing results to a variety of factors, particularly the irrelevance of literacy curricula to the productive activities of women beneficiaries, the effect of profound social and gender hierarchies that blunt the impact of literacy (Dighe, 1992; Puncher, 2003; Stromquist, 1990) and the absence of a well-stocked literate environment (Easton, 2014). The combined effect of these factors may severely handicap usage and retention of the skills acquired.

\subsection{New Literacy Studies}

The present study is informed by the developing field of the "New Literacy Studies" (NLS) and its critical analysis of the concept of literacy as a social practice (Barton and Hamilton, 1998; Street, 1984). Over the past three decades, a new generation of researchers in the fields of social anthropology, education, linguistic and development studies has begun turning its attention to the everyday literacy- and numeracy-related practices of literates, semi-literates and illiterates alike. NLS proponents conceptualize literacy as primarily a social practice, a conceptual model that allows them to question common assumptions about the direct linkages between literacy and a variety of socio-economic development effects. In place of attributing individual and social development effects directly to literacy, NLS scholars focus on understanding the varied actual ways in which people succeed in applying literacy and numeracy skills to the sociocultural context in which they live (Robinson-Pants, 2004; Street, 2004); and they argue that mapping literacy curricula on such insights offer a more promising way of designing programs. At the same time, they point out that such practices may vary markedly across cultures and social circumstances and that these differences must be recognized. The scope and number of New Literacy Studies are expanding, and fields of investigation have begun to multiply (Andrew, 2011; Bass, 2012; Carter, 2006; Jacobs, 2008; Walsh, 2010). A critical gap in this scholarship must nonetheless be noted.

New Literacy Studies concentration mainly on research participants who have never been to school but claim they perform literacy and numeracy that have resemblances with graduates of formal schooling helps us understand a variety of literacy practices outside the official education system. These practices can be co-opted in programs that support literacy learning and particularly for adult learners. It also effectively argues against the outright condemnation of anyone who does not read and write in the conventional form and recognized written languages as illiterate for the point of view that people can be illiterate in one context but literate in another. Thus, the use of New Literacy Studies theoretical approach in analyzing literacy as a social practice has been a successful rebuttal to common assertions about the independent effect of literacy on development in the works of scholars Goody (1986) and Ong (1982).

The exclusive focus on non-schooled literacy practices to the exclusion of those with formal schooling, however, does signal some misperception around whether local practices only evoke literacy and numeracy uses by people who have never been through formal education rather than implying potential differences in the way people use literacy across different socio-cultural settings. The uses for literacies and numeracy across societies of various cultural groups is essentially the crux of the socio-cultural practice theory and that interest should allow for more expansion in our sampling, whether study participants are purposively or randomly selected. Therefore, including people with some formal schooling as is the case in the study this paper draws on will expand knowledge in meaningful ways by illuminating how school dropouts in settings such as The Gambia employ whatever literacy and numeracy skills they have acquired and retained over time from their participation in formal schooling.

Additionally, Ever since Moser's seminal work (1989), gender and development researchers have recognized that women in developing societies, in fact, exercise a variety of occupations and perform diverse gender roles. The connection between that complex reality and women's literacy practices in Sub-Saharan Africa, however, is rarely highlighted, with the exception of insights to be found in a few studies (e.g., Gebre et al., 2009; Puchner, 2003). There is, therefore, a critical gap in knowledge regarding the current gender roles of Sub-Saharan Africa women and particularly those relating to their economic activities and the utilization of literacy and numeracy skills in such roles. It is argued in this article that an understanding of women's actual uses of literacy and numeracy helps greatly clarify the economic activities that they perform in the communities where they live.

\section{Methods}

\subsection{Study Purpose and Setting}

The present study is designed to help fill the gap in the study of women's literacy practices just highlighted, and to do so by illuminating the actual ways in which women with limited educational qualifications in urban settings of developing countries such as The Gambia actually apply literacy skills to their daily activities within the informal economy as well as the constraints that weigh on their use of these skills. It is important first, however, to place that discussion in the context of larger Gambian society and the socio-economic landscape within which the women live. 
The Gambia remains extremely poor, ranking 165 th out of 187 countries for which the UNDP Human Development Index (HDI) of 2013 offers comparable data. Survey results of 2005/2006 and from which the estimation of Gambia's Multidimensional Poverty Index (MPI) reported in the UNDP HDI (2013) is derived suggest that 60.8 percent of the population are multidimensionally poor while an additional 15.7 percent are near multidimensional poverty. Additionally, 33.6 percent of The Gambian population live below the official income poverty line, pegged at $\$ 1.25$ a day. The climatic patterns of the country only ensure seasonal rain; thus rainfall-dependent agriculture, on which almost 80 percent of the population relies can only be practiced for about three months a year. The persistent poverty in the country means in addition chronically anemic demand for paid labor and low agricultural productivity, compounded in turn by weak redistributive policies, especially in public social services, and the absence of support mechanisms for the poorest households (International Monetary Fund, 2007). Women are particularly disadvantaged in this poverty situation although regional disparities are evident from one section of the country to another. Most income-earning women are selfemployed, and collectively they represent about 62 percent of the self-employed population of The Gambia. Many of these women have never attended formal school (International Monetary Fund, 2007).

The Gender Inequality Index (GII) of the HDI report shows that Gambian women are disadvantaged in three key areas: reproductive health, socio-political empowerment, and economic activity. In the most recent available figures, 72.4 percent of women are employed in one fashion or another compared to 83.1 percent of men (UNDP HDI, 2013). In urban Gambia, the current study finds that most women work in the informal economy where they earn very meager wages as street vendors and domestic servants. When economic activities are combined with indicators of reproductive health status, maternal mortality and adolescent fertility rates, the resulting Gender Inequality Index for The Gambia (0.594) ranks it $128^{\text {th }}$ out of 148 countries.

Serekunda, the setting in which this study was conducted, is a section of the Kanifing Municipality on the outskirts of the Banjul, the country's capital. It is, in fact, the largest urban agglomeration in The Gambia and is located a few kilometers inland from the coastal area of Kololi and Kotu. Its population is multi-ethnic and composed of people of different religions and linguistic backgrounds. Here as in other urban areas of the developing world examined by Baker (2010), high levels of poverty severely affect social welfare indicators like life expectancy, nutrition, education and health. It is this increasing poverty, coupled with high unemployment rates that forced women with limited education to assume roles that transcend their traditional family care provider and community management functions (International Monetary Fund, 2007). They have done so mostly by participating in the informal economy as a means to alleviate the chronic poverty of their households.

There is no data on average literacy rates for Serekunda women between the ages of 18 and 49 years (the age bracket that participated in this study), but national literacy data for fifteen years and older from the 2003 census for the Kanifing municipality, which Serekunda is a part of, revealed a 50 percent women and 70 percent male literacy rates. As an administrative area, found in urban Gambia, Kanifing has better literacy rates that in other regions that are not in proximity to the capital, Banjuli. The most recent UNESCO data (2015) on the literacy rates of The Gambian population of aged 15 and older reveals that 63.91 percent of male and 47.6 percent for female are literate. Data on the educational attainments of the study participants and their literacy and numeracy competence levels assessed by the author of the current article revealed very low levels of educational achievements and literacy and numeracy competencies. Although 73 percent of the 120 women who took part in the study had some formal schooling, only 37 percent of them had more than six years, averaging five years. Similarly, only 10percent of the women participants were able to read sentences and paragraphs sentences about everyday life in either English or an African language of The Gambiai ${ }^{\text {ii }}$, whereas 22.5 percent could read words used in everyday sentences; 20 percent could read a simple sentence about everyday life and a quarter of the women could not read at all.

As a consequence, there are in fact a number of adult literacy programs targeted at urban and rural women with limited to no literacy attainments that use African languages as a medium of instruction ${ }^{\text {iii. }}$. Provision in Serekunda has therefore improved, and the community offers a promising setting for studying the interaction of literacy supply and demand among urban women and for contributing to a better understanding of the interactions between African women's economic activities and their use of literate and numerate skills.

\subsection{Study Methodology, Participant Selection and data collection and analysis}

Given the purpose of the research was to understand urban Gambian women's usages of literacy and written numeracy and how these are relevant to their daily lives, the qualitative-interpretative approach was adopted as a means of studying the phenomenon holistically (Denzin \& Lincoln, 1994). The study relied on the experiences of the study participants, augmented by the researcher's personal observations of the contexts in which activities provided the medium to analyze the research questions. The study employed an ethnographic approach, following other New Literacy Studies (e.g., Maddox, 2005) for providing a detailed description of the socio-cultural context in which literacy-related activities take place, gender roles in that environment; and the functions of literacy therein.

Purposive criterion sampling (Patton, 1990) was used for selecting study participants who satisfied the criteria for participation in the study. The study participants are constituted by adult Serekunda women with modest levels of educational attainment. "Modest" is defined as formal schooling up to but not exceeding a complete secondary/ High school education. In fact, the women who participated in the study have acquired some level of literacy by a variety of means: differing amounts and combinations of primary schooling, non-formal education, religious training and self- 
directed learning. The target group was between 18 and 49 years of age, are active participants in reproductive, economic and community management functions and resides in the four principal towns that compose the urban community of Serekunda: London Corner, Dippakunda, Bundung, and Tallinding. The study participants, a total of 120 women who met the study criteria described above were selected from ten women groups. Women's groups abound in the study setting and are used by the women as a platform for discussing and organizing community social and economic activities.

Data collection proceeded through three different stages: ethnographic survey, focus group discussions, and individual interviews along with participant observations. The ethnography survey collected demographic data from 120 women on the women's socio-economic status, level of education, and literacy abilities.

The number of participants selected for the focus group was based on the results of the survey and narrowed down to twenty women who met the sample characteristics noted above. Two groups of women with mixed literacy ability levels (i.e., low or high literacy skill levels) were selected to participate in the discussions. The discussion session for each group (ten members each) was held separately for the purpose of comparing and contrasting the perspectives of the two groups of women on the focus group discussion questions (Morgan, 1997). The interaction that I have had with survey respondents and the initial field data facilitated my identification of participants who are "information-rich" on the research questions that were addressed during the second phase of the study.

The individual in-depth interviews and the participant observation phase was characterized by actual observation and "shadowing" of the study participants. I participated in the daily activities of the women who took part in this phase of the study. The women were all active in one or more economic activities at the time of the study but again have mixed literacy ability levels. By participating in the day-to-day operations of the women, I was able to witness firsthand the daily experiences of the women in running their economic activities and opportunities or lack thereof for the uses of literacy and written numeracy skills in those economic activities. I complemented the shadowing of the women with unstructured and semi-structured interviews to discover the perceptions and values that women assigned to their roles and activities within the context of the study's research questions.

The researcher utilized mainly two of the indigenous languages -Wolof and Mandinka- widely spoken in the study setting to allow the study participants to express themselves effectively in a language they can use for a sustained and lengthy discussions. I, the researcher, translated all the interview transcripts from the local languages used in English ${ }^{\text {iv }}$. The methodological instruments for data collection applied in this paper are presented in author's dissertation (see Njie, 2013).

The survey data was the first that was analyzed for garnering information on the demographic characteristics, educational history and literacy ability levels of the participants. The Statistical Package for the Social Sciences (SPSS) software was used for frequency distributions and cross-tabulation in a bid to generate information on the overall patterns of demography and literacy levels of the study participants.

The qualitative data- interviews and participant observations data were analyzed together. The analysis of the qualitative data included categorizing or data reduction through the use of coding (Maxwell, 1996, Miles and Huberman, 1994). The categorization process facilitated the capturing of recurring themes across the different data sources as well as the comparing and contrasting of the participants' perspectives on the research questions. From the categorization of themes, conclusions were drawn and findings verified through member checking with the study participants. Given the large scale data that was generated from the study, the qualitative data software, Nvivo was utilized for the qualitative data analysis.

The study was conducted in conformity with the terms and conditions of the study's Institutional Review Board (IRB) approval stipulations. One of the conditions and applied here required the use pseudonyms in reporting the women's perspectives.

Although the research this paper draws on covers literacy uses in home care work, economic activities and community management services, the women's literacy and written numeracy practices- and lack thereof- in the economic activities of the study participants are the only ones reported here.

\section{Findings}

\subsection{Urban Gambian Women's Economic Activities}

Women in urban Gambia, results of this study reveal, have a high level of participation in remunerative work, mainly through self-employment in small businesses with the informal economy - both in the market and in local neighborhoods -- that generate very low profits. Starin's (2009) research on Gambian women's income-generating activities confirms most are petty traders with very limited stock. Starin (2009) observes that:

Gambian markets are hives of activity, but the women often have only a handful of goods to sell. Small clumps of tomatoes, chili peppers, tiny bananas, garlic, plants from the forest and ground nuts are spread out on plastic rice sacks and burlap bags in the hope that they will be purchased by the end of the day (p.22). 


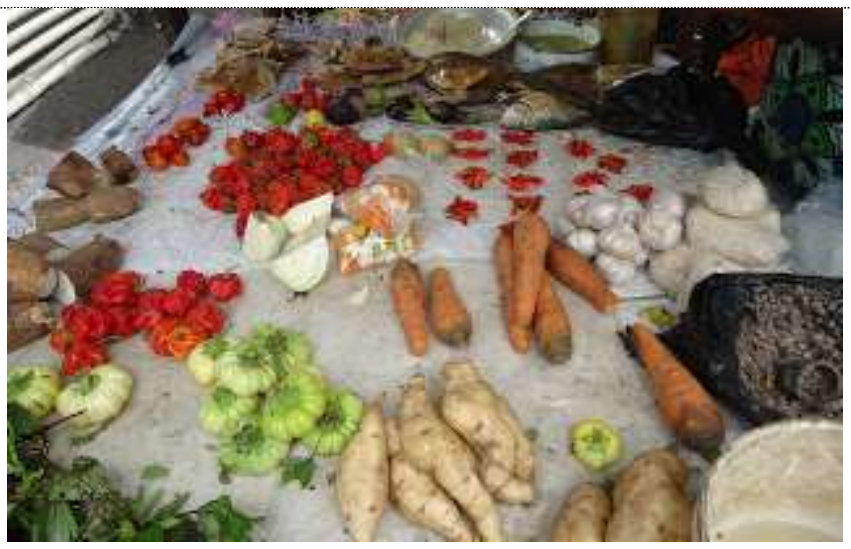

Figure 1. Archetypical market offerings and inventory of women in urban Gambia, from the researcher's collections

Starin (2009) was observing economic activity in rural Gambia, but arguably, both urban and rural women petty traders suffer from the lack of capital that limits women to small-scale trading activities. The study participants were engaged in a wide variety of petty trading activities in the market and their neighborhoods. That spectrum is summarized in Table 1 .

Table 1. Women's employment patterns

\begin{tabular}{ccccccc}
\hline & \multicolumn{2}{c}{ Paid Work } & \multicolumn{2}{c}{ Type Of Work } \\
\cline { 2 - 5 } Age Group & Yes & No & Petty Trading & Menial Jobs & None & Total \\
\hline $18-24$ & 15 & 13 & 10 & 3 & 12 & 28 \\
$25-29$ & 15 & 4 & 12 & 4 & 9 & 19 \\
$30-39$ & 25 & 12 & 19 & 9 & 8 & 37 \\
$40-49$ & 36 & 0 & 26 & 8 & 0 & 36 \\
TOTAL \% & 75.8 & 24.2 & 55.8 & 20 & 24.2 & 120 \\
\hline
\end{tabular}

Fieldwork, 2012

Further analysis on the women's types of economic activities shows that of those women in petty trading, 72 percent sell comestibles and local beverages, including seafood and vegetable vendors. A small percentage are in the locally-made soap and tie-dye business or are frequent travelers to Senegal where they buy clothes, shoes, jewelry and cosmetics for resale in The Gambia (18.3 percent). Outside of petty trading activities, 22 percent of the women work as domestic servants in hotels, offices, and households of affluent community members.

Overall, more than three-quarters of the survey respondents were making a living of some sort in the informal economy and the rest were - at least at the time of the study - sidelined from income generating work by lack of capital to buy stock and lack of time due to the burden of family responsibilities. A focus group participant typified women's productive activities in urban Gambia and suggested the underlying rationale for women's participation in productive work:

The role of women has changed. Formerly women had a lot of leisure time to relax at home in the evenings. Women having enormous time is hardly the case anymore. Mostly women are in the retail business as petty traders. We sell everything from cooked food, smoked fish, fresh fish, meat, incense, rice, cosmetics, and lowcost sewing materials to firewood -- and the list goes on and on. Some men leave the family upkeep [entirely] to the women. Nonetheless, women keep on working hard.

Persistent themes throughout discussions with study participants were, on the one hand, the hardships that women endure in contributing economically to their households and, on the other, the reason they continue struggling with the difficulties -- for the sake of Allah and their many family members, but not simply to please their husbands. Many married women live in an extended family set-up - nieces, nephews, siblings and relatives in addition to their children -- where they are expected to provide nutritious food for the whole family out of the proceeds of their petty trading.

"In spite of all the efforts and sacrifice, the women receive little or no gratitude from the members of an extended family set-up," a focus group participant commented. 


\subsection{Women's Literacy and Written Numeracy Practices in Economic Activities}

The vast majority of everyday literacy and numeracy practices of the women observed during the study related to their productive gender roles entailed by the conducting of petty trading activities. The increased participation of women in the informal economy has to some extent expanded their interaction with literacy and written numeracy. In that regard, the practices mostly revolve around record keeping for small informal economy business endeavors. As one participant explained,

Some women write. In my shop, I record sales and keep track of stock on a daily basis. Women who don't write are very gifted in keeping records mentally. They manage to keep detailed [mental] records of every transaction. However, it is better to keep written records of those business transactions, as some customers default in their payments. Sales are mostly made on an installment basis. Records will show any down payment and every partial payment up to the end for every transaction. The bigger the business, the better it is to keep written records. When we travel overseas [mostly to Senegal], we generally have to make a written declaration of goods at the border customs posts. Unless the quantities are recorded, you could misdeclare the amounts and have trouble in clearing your goods.

Study participants confirm that women who are not literate and numerate manage to keep mental records of their petty trading activities, and most have been very effective in doing so. Women who are not functionally literate seek help from others if they must read, write, or perform written calculations.

The cases of four women with differing literacy skills and different productive uses for them are presented below. They provide grist for analyzing productive uses of literacy and numeracy among women of the Banjul periphery and for situating their literacy and written numeracy practices within the reality of their economic activities.

\subsubsection{Isatou, a Grade Five School Dropout and a Janitor}

Isatou, a study participant who was 39 years old at the time of the interviews, had limited formal schooling, like many women of her age who took part. She dropped out of school in grade five because she was asked to repeat the grade after failing the examination for promotion to grade six. By the time of this research, she had very low reading and numeracy skills. Her reading score on the tests administered to determine study participants' levels indicated that she was only able to decipher syllables used in everyday written words but not able to derive meaning from words. Her score in written numeracy, though, was appreciably better, and she demonstrated an ability to transcribe numbers and simple additions and subtractions with carry-over. Isatou's first job was like a bar waitress. From that job, Isatou learned to take orders from customers and prepare bills. Reminiscing, she explains:

I did not do well in school and was told to repeat grade five, but I chose to drop out instead. I got a job as a waitress, at which I did quite well. I prepared my bills for customers, adding up and listing the drinks served. Now I have forgotten all of that. The longer you stay away from using literacy skills, the more you forget. Many women in my situation would have to get back into in an adult learning program of some type to recall lost skills.

Currently, Isatou works as a janitor at a government office. Her husband earns a meager income as an auto mechanic in a local garage. She is swamped with financial responsibility and needs an additional source of income to support her family. In order to augment her income from her current job, Isatou runs a shop, as a joint investment with her sister, at her house where she sells basic items such as food seasoning, batteries, sugar, green tea, and candies. Managing both the janitoring and shop-tending jobs along with her family responsibilities has proven to be harder for her than for women who live in extended families and can occasionally enjoy the support of other family members in carrying out household chores. Isatou has to juggle all her reproductive and productive activities on her own since she lives in a nuclear family. Her daily routine includes cooking meals for the family after her cleaning job and fitting shop management between the two. She described her daily routine thus:

When I wake up, I wash up and give my children a bath, and then I rush to get on a neighbor's car that takes me to Banjul for work at a lower cost than public transport. At the office, I clean -- that is, I sweep the rooms, corridors and stairways. My work shift ends at 12:00 or latest at 2:00 pm. When I get home, I clean the house and start to cook the day's meal. After, I open the shop.

Isatou has a bank account, as required for her janitorial job. As her employer, many institutions in The Gambia have transferred monthly salary payment functions to banks for more efficient administration. Although she is quite familiar with banking procedures, Isatou does not know how to write a check. At the bank, she seeks help for writing her checks but avoids approaching anybody in the open hall because she does not wish to be known as illiterate. "I do want to be counted as literate," she says. "I have at least been to school, and I hope through my effort to improve my status."

As a novice in store management, Isatou lacks related business experience -- and her low numeracy skills prevent her from keeping an accurate account of sales. During one visit to her store, we discussed record keeping for her business, and she offered the following explanation: 
I have not yet started keeping records of the shop's business transactions because I don't have the ability to record sales and stock of items that need to be purchased. Although a lot of women without literacy and numeracy skills can do mental calculations without any writing, I would sooner or later need someone to help me keep records of the business. It is hard for me to know the profit made on each item or even the overall profit made from sales since I am selling different things in this store, as you can see. I can tell by looking at the store, though, that the business is improving since I only started out with a few items and the store is growing. I have tried many businesses like selling food for dinner in the neighborhood, but I have always failed in those. I hope that this store will keep improving.

Although Isatou's goal is to expand her business and then - if she is successful -- retire from her janitorial job, she relies on good luck to ensure the smooth running and growth of her business, with no means to wield the financial literacy and numeracy tools that many would consider necessary.

\subsubsection{Ida, the Emerging Businesswoman}

Ida's case contrasts with Isatou in portraying a situation where reading, writing and numeracy skills are frequently applied in the productive activities of a school dropout. Ida was 23 years old at the time of the study. Her mother told me that Ida had been gifted in school. Her father passed away when she was in early primary school, leaving her mother as the sole breadwinner of the family. Ida dropped out of school in the ninth grade, after passing the national examination for senior secondary school due to lack financial sponsorship. She currently can read a paragraph of sentences used in everyday life, and can also multiply and divide with remainders.

Ida got married two years after she dropped out of school. As a young mother of three, she has learned to support her children's education financially to give them a chance she never had. She is actively involved in the informal economy as a petty trader to ward off financial difficulties. Ida explains that her husband is financially poor because he is from a low socioeconomic family background. Given her financial situation and that of her spouse, she wasted no time engaging in income-generating activities for her family. From the beginning of her business adventure, Ida takes goods from women who are already well established in their enterprises (like those who go to Senegal, Dubai and China to buy goods). She then goes house-to-house to sell those items to the people she knows for a markup of D5 dalasis on top of the price of each item. Ida explains that the uses of reading, writing, and numeracy are vital in her small trading activity. She discloses her business strategy and its high demand for literacy and numeracy thus:

When I receive the goods, the owners write down the name and prices of the items they are giving me, and I note down that same information in my record book as well. Then I take the goods to my clients. Some women will pay for the goods they have taken from me right away, and others will credit them from me until at a later day when they have cash to pay. I need to keep records of those who purchased on credit, and the prices of the goods they credited. It takes about two weeks for me to finish selling the products to my customers, and I return the money to the women from whom I got the items for sale. I am always careful when it comes to getting the women their monies. I have to maintain credibility at all times because a little mistake might lead them to stop giving me their goods.

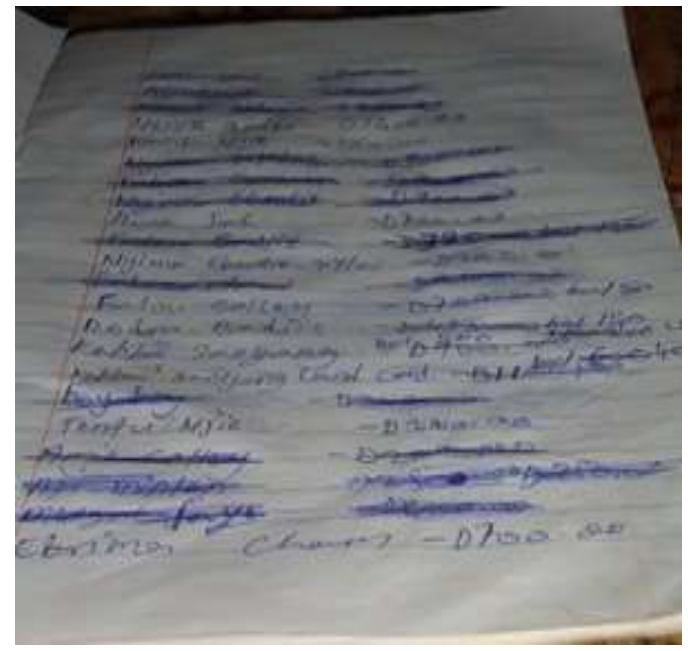

Figure 2. Ida and her record book

Ida asserts that her ability to read, write, and perform numeracy activities greatly aids her in her business. She needs to record business transactions to avoid forgetting from whom she received goods and respective prices since she works 
with different wholesalers. More importantly, she needs to know who has paid off the credit, which she identifies by scratching off the names in her book. Ida has been quite successful and decided to open her store where she sells essential goods, ribbons, and threads, second-hand clothing, and cookware from Europe.

Ida also applies literacy and written numeracy in her second-hand goods business. During one of my visits, she received a phone call from the second-hand store regarding a new consignment. Ida wasted no time in getting ready and invited me to accompany her to the shop, where she moved around with her calculator while negotiating the prices of cartons of dinnerware that she wanted to buy. Before she buys any goods, Ida exercises numeracy skills to ensure that her retail prices (with profit margin included) will remain in the purchasing power of her customers. When we returned to her house, Ida recorded the store prices of the items she had bought. She did not separate the money she earns from the sale of the second-hand goods from those of her consigned goods for smooth cash flow but insisted that this does not confuse her.

\subsubsection{Fatou, Mother of Nine, Food Seller and President of a school's Mother's Club}

Fatou had completed four years of primary education when she dropped out of school to help her elder married sister. She reasons that her parents, like most others, did not see any point in educating a girl child at that time. They were also poor, so could hardly afford the cost. Her mother sold foodstuff to supplement her father's meager earnings. "It is often said that I take after my mom's love for petty trading," she noted. She is a food vendor at a school, and president of the Mother's Club $^{\mathrm{v}}$.

In addition to her limited formal education, Fatou has participated in an adult literacy program. After her group of school vendors had joined the Mother's Club, she started to appreciate the utility of education in daily activities. For instance, learning to recognize numbers could enable her to make phone calls on her own. She would also be able to read text messages, through literacy classes in Wolof or Mandinka. Due to her keen interest in this program, Fatou learned to read and write in Wolof. At an event that showcased adult learning at the National Assembly, Fatou was randomly selected to read aloud from a second grade English book, which she reportedly did very well. The literacy class Fatou attended was in Wolof and Mandinka, and participants had to choose one of the languages. Later on, some adult learners thought it is wise to learn to read in English, because few official documents are written in Wolof or Mandinka. She reported that the Regional Education Office agreed to the community proposal for English literacy classes.

As results of her literacy and numeracy assessment have shown, Fatou can read a paragraph of sentences used in everyday life, and can also multiply and divide with remainders. It was not clear how much her test performance is confounded by her early participation in formal schooling, although her ability to read in Wolof is apparently a recently acquired skill.

As a mother of nine, and given her husband's unstable job and meager income, Fatou is resolved to provide for her family's daily bread. She continuously emphasized how hard times have made women work harder to help supplement the household income and to give their daughters a chance for schooling to avoid the economic dependence or struggles within the informal economy faced by themselves. When her house flooded due to torrential rains, Fatou moved with her family to another community in Serekunda where she found herself a stall on a busy highway to sell breakfast and lunches. She claims that her character does not allow her to sell anything but food, thus:

All the petty trading I have done is selling food which I cook at home and prepare fruit juices to go along. I don't think my character will let me do other types of business, like buying goods from Senegal and selling these on credit. I quickly feel sorry for someone in need. With the food sale business, the prices are affordable, and the particular borrower can easily pay.

She sells a variety of comestibles which include rice, beans, sauces with liver and "akara"- snacks made out of beans. Fatou serves coffee and tea when the weather is not hot, but mostly serves local fruit juice (wonjo) and cold water. She is a shrewd petty trader, particularly in her marketing strategy. Fatou changes her menu every other day to sustain her customers' appetites - learning from two decades of experience in the local food industry. She also understood that her business involves meeting people of all types, so she was patient, open, and humble in her interaction with clients.

At her stall, Fatou has many customers who regularly gather for breakfast and lunch. She did not employ any visual literacy and numeracy skills (e.g. use of a calculator) in her business transactions, even when returning change to her clients who gave her big denominations sometimes. Fatou employed mental calculations in her commercial operations and never even recorded her credits. She committed every business transaction to memory and was very confident and comfortable with her mental calculation and recording skills. Although it took her some time to calculate mentally her customers' change, it appeared that Fatou would continue to cling to her mental calculation technique.

Fatou also does little writing in her role as the president of the Mother's Club and her personal life. Although the group has a book listing all members, and another book for fines and late charges, the group secretary handles those matters. Fatou reckons that the kind of business she does can be efficiently carried out without any literacy or written numeracy skills. She noted, "It feels right to be literate, but I have not found much use for it in my trading activities." Fatou is clearly one of the women who given the nature of her economic activities have little demand for the uses of literacy. 


\subsubsection{Binta, Secondary School Drop-out and Market Vendor}

Binta was 24 years old at the time of the study, and one of seven children in a polygamous family. She and her siblings all attended formal schooling, but she was the only one among three sisters who has some secondary school education. One sister wasn't doing well in school, and her father transferred her to Arabic school, but she eventually dropped out. Her elder sister got married before going to secondary education and left immediately as a result. Her brothers also attended school, but only one of them reached high school and were yet to graduate.

While at the secondary level, Binta also got married -- to one of her extended family members residing in Europe. She disclosed that she did not like being married to a relative, moreover to someone she doesn't know, but was compelled by an uncle:

When they were marrying off my sister, his attention was shifted to me. My first reaction to that marriage proposal was that I am going to school and want to further my education. No one would listen, though. My uncle said that I was too young to decide about my life, particularly with regards to whom and when I should get married. When I could not continue my schooling, I got frustrated. At some point, I decided to sell fruits and vegetables with my mother, in hopes of raising some money to take care of my daily expenses and also to help the family. That was how I got more acquainted with my mother's business. Before this time and when I was going to school, I helped her to sell vegetables during school holidays.

Before her petty trading at the market, Binta taught children at a kindergarten in her community. At the school, she had the opportunity to receive English classes from the school principal. The school closed, however, when the proprietor returned to the United Kingdom.

Compelled to assist her mother financially, Binta became a market vendor and sold vegetables, mainly tomatoes, carrots, cucumber, salads, green bell pepper, or any vegetable that the women gardeners bring to the market. She lamented the denigration that she suffers from her (former) school friends who consider her income-generating activity to be a trade for the non-educated.

Neither at home nor the market did Binta make any use of literacy and written numeracy skills. As a small retailer, she claims not to have written transactions to keep. She has been observed in mental calculations for her little trading activities. Unlike Ida, who uses her literacy and numeracy skills for recording credit transactions to her customers, Binta does not work with credit from her clients. Her only literacy practice is to record her weekly contributions to a saving scheme organized by market vendors. Also, at the market, non-literate women occasionally ask her for help in calculating the cost of a product, something that she can do with the calculator on her cell phone. She acknowledges that she used to be more competent in reading when she was going to school. Currently, she can only follow and understand newspaper content with some difficulty.

\section{Discussions}

The findings presented here on women's literacy and numeracy practices and focused in-depth on the four ethnographic cases point out numerous instances of women's uses of literacy and numeracy, albeit with some nuances. The study demonstrates both positive and neutral impact of literacy on the economic activities of women with modest educational qualifications. It confirms New Literacy Studies theoretical framework of literacy as a social practice, implying that literacy and numeracy practices are ingrained in people's livelihoods (Maddox, 2005) and thus, from the context of the current study, effective literacy learning cannot take place outside of the environment of the women's livelihood strategies.

The study shows that generally, women tend to have limited access to and control over financial resources for use in their economic activities. This finding supports those in the empirical literature that has addressed the gender impediments to women's economic prosperity in Sub-Saharan Africa (Chant, 2007; Darkwah, 2010; Tsikata, 2009). In urban Gambia and as revealed by this study, women are increasingly becoming more involved in the informal economy to survive economic hardships as a result of swelling economic slump. Over three-quarter of the 120 study participants who took the demographic survey of the study, in fact, earn a living from the informal economy and the majority of these women are petty traders. In some cases, the uses of numeracy and particularly efficient record-keeping skills have added competence in managing a small-scale business. For example, Ida practices much writing and written arithmetic in taking goods from multiple wholesalers and noting the items and their value. She also needs numeracy to calculate quickly how much profit she will be able to generate before taking those goods to be sold to her neighbors. The women admitted to mistakes and failure in their business endeavors due to their lack of expertise in financial literacy.

As was the case overall from the study, although few women have the means to keep track of their business transactions using writing and written numeracy skills, the incentive to use the skills were low among some of the women. Many of the study participants preferred mental calculations to written arithmetic because they managed very small-scale economic activities and could effectively fare well in carrying out their economic activities. As an example, Ida assigned a high value to the uses of literacy and written numeracy skills in her small trading activities than Fatou and Binta, who performed their business activities without much need for literacy and written arithmetic despite possessing some literacy and written numeracy skills. The conditions that allow for literacy and numeracy uses are arguably couched in the socio- 
cultural context of their application or what Easton (2014) refers to as the demand and supply factors of the literate environment. Although Fatou is literate and can undoubtedly apply it in her food business, she seems content to let her cultural knowledge of memorizing and recalling customers' names who owe her money guide her commercial transactions, something that she has acquired from her mother who was a food vendor as well. When she was interrogated about the reasons for not writing her business transaction, Fatou replied with: "that was how I learned it from my mom and besides there's not much to write."

Lack of avenue to practice literacy and numeracy skills appears to pose obstacles to literacy retention among school dropouts, as revealed in the case of Isatou and Binta. The lack of opportunity to practice can be attributed to the nature of the women's gender roles and more so the domains of their economic activities that do not often oblige them to perform literacy and written numeracy activities. For instance, although Isatou dropped out of school with weak literacy skills she was nonetheless able to use the skills in her employment as a waitress, a job that required her to read and write orders made by customers. At the time of this study and after almost a decade of having quitted the server job, she could not read or spell the names of beverages that she claimed she used to spell quickly. Similarly, Binta at the time of the study maintained quite some fine levels in both reading and writing but emphasized she had begun experiencing challenges in clearly understanding newspaper contents compared to the past when she used to command the ability to read them effortlessly. The women throughout the study, and particularly preponderant during the focus group discussions, have pointed out the lack of opportunities for constant practice as one of the reasons why retention of literacy skills prove difficult for some of them.

Further, from Binta's case, as a final grade secondary school dropout, the high expectations of human capital theorists (see Schultz, 2002) about the economic returns to girls' education can be contested. Binta's case shows that women with secondary education in developing countries are not already set up to accrue automatically substantial gains from their studies through access to paid employment. In The Gambia and other parts of Sub-Saharan Africa, higher-level schooling attainments continue to rise, in part, due to the availability of university education. However, formal sector jobs have not kept pace with the rising qualification levels of its university-educated job seekers. A mere secondary school certificate does not provide a decent comparative advantage in the formal sector job market. Hence, unemployment and underemployment issues require critical policy concerns for their solutions and particularly in the case of adverting a common pattern of relapsed into illiteracy as was the case of a handful of the study participants.

Additionally, Binta's chances to fully accrue benefits from the restricted employment opportunities school drop-outs of her educational qualification level are limited to in The Gambia were further jeopardized by a particular gendered conditioning epitomized by an arranged marriage to her cousin and one that ended in divorce. Consequently, her low perception of self, due to her material poverty condition, demoralization from a failed marriage and couple with a lack of resources and agency to pursue more ambitious self-development goals, keep Binta stuck in her fruit and vegetable business. Binta noted that her peers often rebuke her income generating activity and associate it with those of the nonliterates. She, however, feels content taking over her mother's business despite its low economic returns. At the time of the study, she lacked an exit plan to escape the vicious cycle of female poverty passed to her from the gendered conditioning of an environment that restrict women's life chances and possibilities.

Moreover, will Binta's and those of many others among the study participants' reading speed and ability decline further over time if they continue to lack the avenue to apply them? This is a critical question with an enormous theoretical and practical implication for literacy learning and related policy development in Sub-Saharan Africa and for which empirical evidence is, unfortunately, lacking. The paucity of knowledge in that area could be attributed to the absence of tracer studies on the subject of literacy retention among school drop-outs in Sub-Saharan Africa. However, in line with the empirical claims that point to the need for sufficient practice before a student can read fluently without a problem (Abadizi, 2006) and even be able to preserve literacy skills (Wagner, 1993) the conditions that allow for constant literacy practices must be fully present. Hence, if Binta continues to have a limited encounter with literacy activities, her ability to maintain her current literacy skills overtime may prove to be a daunting challenge.

\section{Conclusion}

This paper highlighted women's economic activities, the related needs, and uses of literacy and numeracy in those economic activities and as well as some contextual barriers that limit a productive application of the skills.

By employing New Literacy Studies in analyzing the interaction of economic practices and uses of literacy among urban Gambian women of low educational qualifications, the study demonstrates that literacy goes beyond its limited skill view attribute, a conception prevalent in numerous discourses that conceptualized literacy as a decontextualized basic skill. What made literacy and numeracy to be employed or not in women's economic activities was not determined by the skills they possess alone, but by the social and economic functions literacy events served and in which reading and writing were important in the interaction between the women and their economic activities (Heath, 1983).

The women's literacy practices were patterned by values, beliefs, and social relationships. For instance, the recording of the women's weekly Osusu contributions, the recording of their petty trading activities and the recording of financial contributions during social ceremonies (see Njie, 2013), have all proven that literacy practices are embedded in sociocultural life and patterned by social relationships (Barton and Hamilton, 1998). The women petty traders have found the keeping of records either mentally or by writing each and every partial payment clients made until they finish making 
their payments paramount in maintaining healthy relations. Although the mental recording of business transactions does serve its purpose, the women mostly prefer to keep written records even if they have to carry it out with the help of their family members or friends. Following the importance of social relationships in understanding literacy as a social practice, Barton and Hamilton (1998) asserted "literacy practices are more usefully understood as existing in the relationships between people, within groups and communities, rather than as a set of properties residing in individuals" (p. 8). The study findings call for pragmatic strategies to improve learning programs for non-schooled women and those with low educational qualifications, and in ways that opportunities for their economic livelihoods are enhanced, and the sociocultural environments that support the gendering of their live chances are buffered for the enlargement of their capabilities. The solutions to addressing women's poverty and issues of low returns to female education in Sub-Saharan African countries such as The Gambia reside in the formulation of policies that are informed by knowledge of the local literate environment, socio-cultural, economic and gender barriers women face that inhibit their efforts to benefit from the returns to education. Those funds of knowledge are crucial for identifying women's gender constraints, their particular needs for learning in areas they have assigned high value, those that fit their emerging economic practices or add greater efficiency to existing ones.

\section{Acknowledgement}

I wish to thank, Professor, Peter. B. Easton- my dissertation advisor- for his extensive reviews and valuable comments on this article. Peter's erudite insights based on a well-grounded knowledge of more than 30 years of literacy research, literacy program development and delivery in Sub-Saharan Africa significantly contributed to this article. All errors are mine and mine alone. My immense gratitude goes to all the study participants for sharing their lives with me and to the Magaret McNamara Memorial Fund and the Association of American University Women for funding the dissertation research that this study draws on. Valuable comments from the IJELS anonymous referees are greatly acknowledged.

\section{References}

Abadzi, H. (2003). Improving adult literacy outcomes: Lessons from cognitive research for developing countries. World Bank Publications.

Andrew, M. (2011). 'The real world': lived literacy practices and cultural learning from community placement. Australian Journal of Language and Literacy, 34(2), 219.

Baker, J. I. (2008). "Impacts of Financial, Food, and Fuel Crisis on the Urban Poor. Directions: Urban Development. Washington, DC: World Bank, Urban Development Unit."

Barton, D., \& Hamilton, M. (2012). Local literacies: Reading and writing in one community. New York, NY: Routledge.

Bass, T. L. (2012). Cultural brokers in classrooms and the new literacy studies. In Proceedings of Intercultural Competence Conference September (Vol. 2, p. 1-10).

Betts, J. (2003). Literacies and livelihood strategies: Experience from Usulutin, El Salvador, International Journal of Educational Development, 3(3), 291-8. http://dx.doi.org/10.1016/S0738-0593(02)00052-4

Blackden, C. M., \& Wodon, Q. (Eds.). (2006). Gender, time use, and poverty in sub-Saharan Africa (Vol. 73). World Bank Publications.

Blumberg, R. L. (2005, August). Women's Economic Empowerment as the Magic Potion of Development?. In 100th Annual Meeting of the American Sociological Association, August, Philadelphia.

Burchfield, S., Hua, H., Baral, D., \& Rocha, V. (2002). A Longitudinal Study of the Effect of Integrated Literacy and Basic Education Programs on Women's Participation in Social and Economic Development in Nepal. Retrieved from: http://datatopics.worldbank.org/hnp/files/edstats/BOLdprep02.pdf (accessed November 17, 2015)

Carter, S. (2006). Redefining literacy as a social practice. Journal of Basic Writing, 94-125.

Chant, S. H. (2007). Gender, generation and poverty: exploring the feminization of poverty in Africa, Asia and Latin America. Massachusetts: Edward Elgar Publishing.

Chen, M.A (2005) Rethinking the informal economy: linkages with the formal economy and the formal regulatory environment. No. 2005/10. Research Paper, UNU-WIDER, United Nations University (UNU).

Coletto, D. (2010). The informal economy and employment in Brazil: Latin America, modernization, and social changes. New York: Palgrave-McMillan.

Darkwah, A. K. (2010). Education: pathway to empowerment for Ghanaian women? IDS Bulletin, 41(2), 28-36.

Denzin, N. K., \& Lincoln, Y. (2000). Qualitative research. Thousand Oaks, California: Sage Publication

Ltd.

Dighe, A. (1995) Women, literacy and empowerment: the Nellore experience. In Medel-Anonuevo, C. Women, Education and Empowerment: Pathways towards autonomy, Hamburg: UNESCO Institute for Education

Easton, P- (1983) Functional literacy in the West African Sahel: the Operation Arachide project in Mali. In J.C. Bock; GJ. Papagiannis (eds.), 63-86. 
Easton, P. B. (2014). Developing literate environments: Fleshing out the demand side of Education for All. International Journal of Educational Development, 34, 3-10. http://dx.doi.org/10.1016/j.ijedudev.2013.02.003

Fransman, J. (2005). Understanding literacy: a concept paper. The EFA Global Monitoring Report, Literacy for Life. Retrieved from: http://unesdoc.unesco.org/images/0014/001459/145986e.pdf

Gebre, A. H. (2009). Everyday Literacies in Africa: Enthnographic Studies of Literacy and Numeracy Practices in Ethiopia. Uganda: Fountain Publishers

Glick, P., \& Sahn, D. E. (1997). Gender and education impacts on employment and earnings in West Africa: Evidence from Guinea. Economic Development and Cultural Change, 45(4), 793-823. http://dx.doi.org/10.1086/452308

Goody, J. (1986). The logic of Writing and the Organization of Society. New York, NY: Cambridge University Press.

Goody, J. (1987). The Interface between the Written and the Oral. New York, NY: Cambridge University Press.

Günther, I., \& Launov, A. (2012). Informal employment in developing countries: Opportunity or last resort? Journal of development economics, 97(1), 88-98. http://dx.doi.org/10.1016/j.jdeveco.2011.01.001

International Labor Organization (2014). Transitioning from the informal to the formal economy. Paper presented at the International Labor Conference 103rd session, 28 May - 12 June, Retrieved from http://citesource.trincoll.edu/chicago/documents/chicagoconfpaper.pdf

King, E. M., \& Hill, M. A. (Eds.). (1997). Women's education in developing countries: Barriers, benefits, and policies. World Bank Publications.

International Monetary Fund (2007). The Gambia: Poverty Reduction Strategy Paper, https://www.imf.org/external/pubs/ft/scr/2007/cr07308.pdf (accessed October 14, 2015)

Jacobs, G. E. (2008). We learn what we do: Developing a repertoire of writing practices in an instant messaging world. Journal of Adolescent \& Adult Literacy, 52(3), 203-211. http://dx.doi.org/10.1598/JAAL.52.3.3

Kagitcibasi, C., Goksen, F., \& Gulgoz, S. (2005). Functional adult literacy and empowerment of women: Impact of a functional literacy program in Turkey. Journal of adolescent \& adult literacy, 48(6), 472-489. http://dx.doi.org/10.1598/JAAL.48.6.3

Kalman, J. (2002). Everyday paperwork: Literacy practices in the daily life of unschooled and underschooled women in a semiurban community of Mexico City. Linguistics and Education, 12(4), 367-391. http://dx.doi.org/10.1016/S08985898(01)00069-9

Kell, C. (2008). 'Making Things Happen': Literacy and Agency in Housing Struggles in South Africa. The Journal of Development Studies, 44(6), 892-912.

Kes, A., \& Swaminathan, H. (2006). Gender and time poverty in sub-Saharan Africa. Gender, time use, and poverty in sub-Saharan Africa, World Bank Working Paper, No. $73 . \quad$ Retrieved from: http://siteresources.worldbank.org/INTAFRREGTOPGENDER/Resources/gender_time_use_pov.pdf (accessed September 17, 2015)

Lince, S. (2011). The informal sector in Jinja, Uganda: Implications of formalization and regulation. African Studies Review, 54(02), 73-93. http://dx.doi.org/10.1353/arw.2011.0029

Luci, A., Jütting, J., \& Morrisson, C. (2012). Why Do So Many Women End Up in 'Bad Jobs'? A Cross-country Assessment for Developing Countries. The European Journal of Development Research, 24(4), 530-549. http://dx.doi.org/10.1057/ejdr.2011.54

Lynch, J. (2009). Print Literacy Engagement of Parents From Low-Income Backgrounds: Implications for Adult and Family Literacy Programs. Journal of Adolescent \& Adult Literacy,52(6), 509-521. http://dx.doi.org/10.1598/JAAL.52.6.5

Maddox, B. (2005). Assessing the impact of women's literacies in Bangladesh: An ethnographic inquiry. International Journal of Educational Development, 25(2), 123-132. http://dx.doi.org/10.1016/j.ijedudev.2004.11.017

Maruatona, T. (2005). Gender and minority issues in planning literacy education in Botswana. International journal of lifelong education, 24(2), 149-164.

Masika, Rachel, Arjan de Haan and Sally Baden (1997), Urbanisation and urban poverty: A gender analysis, Institute of Development Studies, University of Sussex, Brighton.

Maxwell, J.A. (1996). Qualitative research design: An interactive approach. Thousand Oaks, CA: Sage.

Mein, E. (2010). Women's Literacy and Numeracy Practices Oriented toward Small-Scale Social Action in Northern Mexico. Adult Basic Education and Literacy Journal, 4(2), 86-95.

Miles, M.B. \& Huberman, A.M. (1994). Qualitative data analysis (2nd ed.). Thousand Oaks, CA: Sage.

Mills, K. A. (2010). A review of the "digital turn" in the new literacy studies. Review of Educational Research, 80(2), 246-271. http://dx.doi.org/10.3102/0034654310364401

Moser, C. O. (1989). Gender planning in the Third World: meeting practical and strategic gender needs. World development, 17(11), 1799-1825. http://dx.doi.org/10.1016/0305-750X(89)90201-5 
Njie, H. (2013). Literacy uses and women's gender roles: Ethnography of local practices in peri-Urban Gambian community (Unpublished doctoral dissertation). Florida State University, Florida, United States.

Ong, W. J. (1982). Orality and Literacy: the Technology of the World. New York, NY: Routledge.

Patton, M. Q. (1990). Qualitative evaluation and research methods. Thousand Oaks, CA: SAGE Publications, Inc.

Perry, K. H. (2009). Genres, contexts, and literacy practices: Literacy brokering among Sudanese refugee families. Reading Research Quarterly, 44(3), 256-276. http://dx.doi.org/10.1598/RRQ.44.3.2

Prins, E. (2008). Adult literacy education, gender equity and empowerment: Insights from a Freirean-inspired literacy programme. Studies in the Education of Adults, 40(1), 24-39. http://dx.doi.org/10.1080/02660830.2008.11661554

Puchner, L. (2003). Women and literacy in rural Mali: a study of the socio-economic impact of participating in literacy programs in four villages. International Journal of Educational Development,23(4), 439-458. http://dx.doi.org/10.1016/S0738-0593(03)00015-4

Purcell-Gates, V. E. (2007). Cultural practices of literacy: Case studies of language, literacy, social practice, and power. New York, NY: Lawrence Erlbaum Associates Publishers.

Quisumbing, A. R., Haddad, L., \& Peña, C. (2001). Are women overrepresented among the poor? An analysis of poverty in 10 developing countries. Journal of Development Economics, 66(1), 225-269. http://dx.doi.org/10.1016/S03043878(01)00152-3

Rogers, A. (2001). Problematising literacy and development. Literacy and development: Ethnographic perspectives, 205222.

Robinson-Pant, A. (2000). Women and literacy: a Nepal perspective. International Journal of Educational Development, 20(4), 349-364. http://dx.doi.org/10.1016/S0738-0593(99)00080-2

Schultz, T. P. (2002). Why governments should invest more to educate girls. World Development, 30(2), $207-225$. http://dx.doi.org/10.1016/S0305-750X(01)00107-3

Starin, D. (2009). Notes from the Gambia: A hard life, especially for rural women. World Watch, 22(3) 20-23

Street, B. (1995). Social literacies: Critical approaches to literacy in development, ethnography and education. London: Longman.

Street, B. (2004). Futures of the ethnography of literacy? Language and Education, 18(4), 326-330. http://dx.doi.org/10.1080/09500780408666885

Stromquist, N. P. (1990). Women and illiteracy: The interplay of gender subordination and poverty. Comparative Education Review, 34(1), 95-111. http://dx.doi.org/10.1086/446905

Tsikata, D. (2009). Gender, land and labour relations and livelihoods in Sub-Saharan Africa in the era of economic liberalisation: Towards a research agenda. Feminist Africa, 12 . Retrieved from: http://agi.ac.za/sites/agi.ac.za/files/fa12_feature_tsikata.pdf (accessed December 19, 2015)

UNDP Human Development Report Explanatory Note on 2013 HDR Composite Indices for The Gambia. (2013). Retrieved from http://hdrstats.undp.org/images/explanations/GMB.pdf (accessed August, 19, 2013)

Wagner, D. A. (1993). Literacy, culture and development: Becoming literate in Morocco. Cambridge University Press

Walsh, M. (2010). Multimodal literacy: What does it mean for classroom practice? Australian Journal of Language and Literacy, 33(3), 211.

World Bank. (2011). World Development Report 2012. Gender equality and development. Washington, D.C. Retrieved from

http://econ.worldbank.org/WBSITE/EXTERNAL/EXTDEC/EXTRESEARCH/EXTWDRS/EXTWDR2012/0,,menuPK :7778074 pagePK:7778278 piPK:7778320 theSitePK:7778063 contentMDK:22851055,00.html. (accessed August, 19, 2013)

World Bank. (2013). The Gambia, Country Data. Retrieved from: http://data.worldbank.org/country/gambia (accessed August 8th, 2013)

Yousif, A. (2003). Literacy: An Overview of Definition and Assessment. Paper presented at the UNESCO Expert Meeting: Developing an Operational Definition of Literacy and a Conceptual Framework for Literacy Assessment, Paris. 


\section{Endnotes}

${ }^{\mathrm{i}}$ This disparity stems largely from the inequitable distribution of qualified teachers across the country and who tends to be more concentrated in schools within the urban areas of The Gambia

${ }^{\text {ii }}$ Formal school instruction has currently change from the traditional English -only instruction to the use of African languages in the first three years of primary schooling

iii For a detailed description of the linguistic landscape of this region, and the linguistic backgrounds of the participants see Njie, 2013

${ }^{\text {iv }}$ See Njie 2013 for discussions about my positioning in the study as both an insider and outsider of the study setting

$\checkmark$ The Mother's Club is a brainchild of the Forum for the African Woman Educationalist (FAWEGAM) Gambia chapter. It was formed for increasing parental participation in the educational system as stakeholders. 